\title{
"The next generation, that's why we continue to do what we do": African American farmers speak about experiences with land ownership and loss in North Carolina
}

\author{
Peter Balvanz, ${ }^{* 1,2,3}$ Morgan L. Barlow, ${ }^{1,4}$ Lillianne M. Lewis, ${ }^{1,5}$ Kari Samuel, ${ }^{1}$ William Owens, ${ }^{\dagger}$ \\ Donna L. Parker, ${ }^{1}$ Molly De Marco, ${ }^{2}$ Robin Crowder, ${ }^{2}$ Yarbrough Williams, ${ }^{\dagger}$ Dorathy Barker, ${ }^{\dagger}$ \\ Alexandra Lightfoot, ${ }^{1,2}$ Alice Ammerman ${ }^{1,2}$
}

Submitted 9 November 2010 / Accepted 7 April 2011 / Published online 7 June 2011

Citation: Balvanz, P., Barlow, M. L., Lewis, L. M., Samuel, K., Owens, W., Parker, D. L., De Marco, M., Crowder, R., Williams, Y., Barker, D., Lightfoot, A., \& Ammerman, A. (2011). "The next generation, that's why we continue to do what we do": African American farmers speak about experiences with land ownership and loss in North Carolina. Journal of Agriculture, Food Systems, and Community Development, 1(3), 67-88. http://dx.doi.org/10.5304/jafscd.2011.013.011

Copyright (C) 2011 by New Leaf Associates, Inc.

\author{
Abstract \\ African Americans face institutional and social \\ discrimination. The deleterious effects of discrim- \\ inatory practices continue to be barriers to \\ maintaining the family farm. Discriminatory \\ * Corresponding author: tel. +1 (919) 259-9828; peter.balvanz@ \\ gmail.com \\ ${ }^{\dagger}$ North Carolina farmer \\ ${ }^{1}$ Gillings School of Global Public Health, University of \\ North Carolina at Chapel Hill, 170 Rosenau Hall, CB \#7400, \\ 135 Dauer Drive, Chapel Hill, NC 27599-7400 USA \\ ${ }^{2}$ Center for Health Promotion \& Disease Prevention, \\ University of North Carolina at Chapel Hill, 1700 Martin \\ Luther King, Jr. Blvd., CB\# 7426, Chapel Hill, NC 27599- \\ 7426 USA \\ ${ }^{3}$ FHI, 2224 E NC Hwy 54, Durham, NC 27713 USA \\ ${ }^{4}$ Duke Global Health Institute, 310 Trent Drive, Trent Hall, \\ Rm. 334, Duke Box 90519, Durham, NC 27708 USA \\ ${ }^{5}$ Duke University School of Medicine, DUMC 3005, Durham, \\ NC 27710 USA
}

lending is associated with farmland loss, such that the number of African American farmers in the United States has been falling at a much higher rate than that of White farmers. This community-based participatory research (CBPR) study sought to give voice to the experiences and perceptions of a small group of African American farmers in northeastern North Carolina. Researchers used Photovoice, a qualitative CBPR methodology, to identify strengths, concerns, and action steps in regards to farming and farmland loss in the community. This study revealed positive protective factors associated with farming, and long-lasting negative economic and psychological effects of discriminatory lending. Protective factors include increased self-reliance, strong work ethic, and hope for a new generation of African American farmers. Institutional discrimination remains a reported risk factor against maintaining generational family farming activities. Study participants reported a fear of further loss of the African American farming heritage as they perceive youth being deterred from the profession 
due to the combined effects of witnessing discrimination against their parents and the lure of fast, and often risky, money. This preliminary research revealed that African American farmers in the community of this study would benefit from innovative and engaging programs for youth, broadband internet access, and continued modification to current lending systems, including localized representation.

\section{Keywords}

Discrimination, community-based participatory research, African American, land ownership, Photovoice, farming

\section{Introduction}

African American farmers are historically important contributors to agriculture in the United States. In the era of slavery, White landowners sought the expertise of African slave farmers to improve crop cultivation, production, and animal husbandry (Hinson \& Robinson, 2008). After the Civil War the number of African American farmers proliferated, peaking in 1920, when nearly 926,000 individuals worked farms. In that era of small-scale farming there was approximately one African American farmer for every six White farmers in the country (Wood \& Gilbert, 2000). After 1920, the number of African American farmers decreased, and at a much faster rate than farmers in other demographic groups (Wood \& Gilbert, 2000). The 2007 Census of Agriculture counted 41,024 African American farmers, equivalent to 1 in 80 farmers (U.S. Department of Agriculture [USDA], 2009a). Wood and Gilbert (2000) report that 15 southern states experienced the greatest decline in African American-owned farms, with a $45 \%$ reduction between 1982 and 1997. Among these, North Carolina experienced the greatest loss at $66 \%$.

On average, approximately the same percentage of African American farmers and the national average of all farmers combined currently report farming as their primary occupation ( $44 \%$ and $45 \%$, respectively), but African American farmers have less land (an average of 104 vs. 418 acres) and receive less in sales (US $\$ 21,340$ vs. US $\$ 134,807$ ) (USDA, 2009a). African American farmers are older, on average, than farmers of other ethnic and racial groups. A greater proportion of African American farmers are 65 years or older compared to the national average for all farmers $(37 \%$ and $30 \%$, respectively), and the average age of the African American farmer (60.3 years) is higher than the overall average (57.1 years) (USDA, 2009a).

Specifically in North Carolina, as of the 2007 Census of Agriculture, there were 1,837 African Americans farmers operating 1,595 farms, and 1,447 African American farm owners who owned an average of 60 acres (USDA-NASS, 2011a). Comparatively, there were 72,716 White farmers operating 50,897 farms, and 47,874 White farm owners who owned an average of 100 acres (USDA-NASS, 2011a). From 1992 to 1997, African American farmers experienced a greater decline in the number of farmland owners $(-19 \%$ vs. $-3 \%)$ and a decrease in the amount of acreage owned $(-9 \%$ vs. $+4 \%)$ as compared to White farmers (USDA, 2009b). This decrease in African American land ownership, whether reflecting outright loss of farms or loss in acreage, interferes with the viability of African American farmers. Land is a form of wealth that can be used for economic development, broader investment, and has been associated with higher educational achievement in children (Gilbert, Sharp, \& Felin, 2002).

A number of factors contribute to the rapid and continual decline of farmland owned by African Americans. The initial decrease in African American-operated farms is attributed to increased farm mechanization and the end of the sharecropping system (Wood \& Gilbert, 2000). Recent factors associated with the decline in the number of African American farmers are argued to be not the result of economic trends alone, and to include: structural changes by U.S. agriculture favoring large farms, cumbersome tax laws, mortgage foreclosures, intestate death of landowners in the absence of a will and the resulting partition sales, and discrimination (Brown, Christy \& Gebremedhin, 1994; Gilbert, Sharp, \& Felin, 2002; Hinson \& Robinson, 2008). Discriminatory lending practices on the part of the U.S. Department of Agriculture 
(USDA) included not providing African American farmers with access to credit, granting less credit to African American farmers than White farmers, and distributing loans to African American farmers too late in the farming season for maximized farming production (Gilbert, Sharp, \& Felin, 2002; Hinson \& Robinson, 2008).

The negative effects of discrimination by race are broad and far-reaching. Racism negatively influences physical health, mental health, and socioeconomic opportunities Jones, 2000; Paradies, 2006; Brondolo, Brady ver Halen, Pencille, Beatty, $\&$ Contrada, 2009). The association of race and socioeconomic factors is rooted in historic events that persist in contemporary institutional structures (Jones, 2000). Institutional racism, defined as the organization and promotion of racial inequity through processes and structures, has a generational impact (Jones, 1997). The historical discrimination practiced by the USDA is an example of institutional racism.

In response to discriminatory practices, African American farmers throughout the country filed grievances against the USDA. An eventual classaction lawsuit led by plaintiff Timothy Pigford of North Carolina reached the U.S. District Court for the District of Columbia with then-U.S. Secretary of Agriculture Dan Glickman as the defendant. The court decided in favor of the farmers and the resulting multibillion dollar settlement from Pigford v. Glickman was the largest civil rights settlement in U.S. history (Hinson \& Robinson, 2008). A USDAcommissioned investigation into these discriminatory practices also led to the Civil Rights Task Force recommending 92 changes to address racial bias as a part of the USDA Civil Rights Action Plan (Cowan \& Feder, 2010). Since the Pigford v. Glickman ruling, the USDA has broadened outreach efforts to African American farmers through the establishment of the Office of Minority and Socially Disadvantaged Farmers Assistance, which includes the Minority Farm Register to promote equal access to USDA farm programs (USDAFSA, 2007) and a grants program (USDA, 2003). The USDA Small Farmers Outreach Training and Technical Assistance program in particular is a highlighted effort resulting in an increase in the number of African American farmers (Gilbert, Sharp, \& Felin, 2002). At the state level, the North Carolina Department of Agriculture \& Consumer Services (NCDA\&CS, 2011) instituted the Small Farms Ag Policy to provide outreach and education to minority and traditionally underserved farmers.

In the wake of the Pigford settlement, plaintiffs seeking restitution found the procedures overly burdensome, including the requirement to obtain records from a similarly situated White farmer to provide evidence of preferential treatment (Hinson \& Robinson, 2008). Many also found the time period allotted for claims submissions too short to produce the "evidence of discrimination" required. The 2008 Farm Bill opened an opportunity for farmers filing late to receive federal determination of their claims. Numerous cases representing over 25,000 farmers were consolidated into a new lawsuit, In re Black Farmers Discrimination Litigation (Pigford II), which awarded African American farmers an additional $\$ 1.15$ billion in appropriations through the Senate-passed Claims Resolution Act of 2010 (H.R. 4783) approved by the House of Representatives and signed by President Obama on December 8, 2010 (Cowan \& Feder, 2010).

Despite USDA discrimination on African American farmers cited in the literature above, and the resulting reparations and programs, a more recent study in Georgia found no evidence of discrimination on nonwhite borrowers based on the probability of a Farm Service Agency (FSA) loan application's approval (Escalante, Brooks, Epperson, \& Stegelin, 2006). Lending criteria has included subjective "risk stereotypes," however, and the FSA loan review board comprises locally elected farmers who are generally White, with a few exceptions (Havard, 2001). This present preliminary study sought to give voice to the individual and community experiences of African American farmers in rural North Carolina, to shed light on their experiences and perceptions of discrimination, as well as their hopes for the future of African American farming in the region. 


\section{Methods}

Principles of community-based participatory research (CBPR) were used in this study (Israel, Schulz, Parker, \& Becker, 1998). One aspect of CBPR includes blurring the distinction between researcher and participant by creating a coresearcher relationship among all members, thereby minimizing power dynamics common in research and maximizing mutual engagement. For clarity, this report uses the word "researcher" to refer to graduate students and university mentors, and "participant" to refer to farmer collaborators.

\section{Recruitment}

Participants were recruited with a convenience sampling method. Efforts to secure a broader sample were stifled by the relatively small number of regional African American farmers, distance between farms, and declined participation in a couple instances. Participants were sought through personal, academic, and African American farmers' social networks. Researchers approached African American farmers at home, local farmers' markets, and farming meetings to seek participation. Two farmers who eventually agreed to participate were introduced to us at a land loss summit in North Carolina by an African American farmer activist attending the meeting. Additional participants were secured through the network of farmers attending that meeting.

In the three northeastern North Carolina counties that encapsulate this study's area, at the time of the 2007 Census of Agriculture there were 122 African American farmers with 104 farms and, comparatively, 1,473 White farmers with 1,027 farms (USDA-NASS, 2011b). Overall, approximately $90 \%$ of all farmers are White, $7 \%$ are African American, and 3\% report a different race or multiple races. County-level statistics from the 2007 Census reflect single-race categories; individuals reporting multiple races are featured in a separate category, multiracial. National and state statistics cited in this paper for African American and White categories reflect responses of either single race alone or in combination with other races.
Data for age, acreage, and income of farmers was not available for all three counties represented above. Statistics from two neighboring counties, and inclusive of one county in the sample, however, indicated that African American farmers in this region are older than their white counterparts (64 years vs. 60 years), and have smaller land holdings (70 acres vs. 240 acres) (USDA-NASS, 2011b). At the national and state levels, all farms on average were profitable in 2007 regardless of White or African American classifications. In contrast, at the county level in this study, whereas White-owned farms continued to be profitable overall, African American farms had a negative income. Net cash income for African Americanowned farms was negative, at -US $\$ 186,000$, averaging -US $\$ 2,038.50$ per farm and, for White farmers, was US $\$ 6,555,000$, averaging US $\$ 10,398.50$ per farm (USDA-NASS, 2011b).

A site located conveniently within an approximately 20 miles radius of all participant farms, was selected as a central meeting place. Historically, this community has benefited from manufacturing industries such as textiles, tobacco, and cotton for economic growth. ${ }^{1}$ Recently the prevailing industries have changed to include retail, and educational, health, and social services. Agriculture makes up less than $1 \%$ of industry, and less than $1 \%$ of the population serves in farming, fishing, or forestry as a vocation.

\section{Participants}

The five individuals who agreed to participate in this study (four males and one female) had varied educational and professional experience. All five attended college. Among them, two had had careers as high school teachers in eastern North Carolina, one worked in city government in New Jersey, and another was a computer operator for large corporations. Two participants worked at a nonprofit organization dedicated to protecting minority-owned farmland, two were predominately hog farmers, and one was a vegetable farmer. All but one farmer supplemented her or his farm

\footnotetext{
${ }^{1}$ Reference excluded to maintain confidentiality.
} 
income with other forms of employment. All of the participants were exposed to farming as children, left their homes to seek alternative opportunities, and ultimately returned home to northeastern North Carolina for farm-related employment. For further participant demographics, see table 1.

\section{Procedures}

Photovoice, a CBPR method that uses participant photography to trigger discussion, was used to gather qualitative data. Photography is a tool used in recent history as a form of ethnography, to convey information and to document social change (Harper, 2003). The use of photographs both to investigate and to create dialogue on competing and complementary meanings is well documented (Harper, 2003). Photovoice combines and transforms the traditional purposes of photography and critical dialogue into participant and researcher dialectic. In this reference, dialectic is the process and discovery of understanding truth through mutually engaged conversation. Since its inception, Photovoice has been used in a growing number of projects to investigate a range of health and social issues, and has been effective in engaging hard-toreach populations, including those mistrustful or resistant to research (Catalani \& Minkler, 2009). The small sample sizes and nonrandomization often associated with Photovoice projects open the method to bias. The scope of the method,

\section{Table 1. Participant Demographics Related to Farming}

\begin{tabular}{|c|c|c|c|c|c|}
\hline & Farmer A & Farmer B & Farmer C & Farmer D & Farmer $\mathrm{E}$ \\
\hline Age (years) & 62 & 60 & 71 & 45 & 60 \\
\hline Sex & Male & Female & Male & Male & Male \\
\hline Education & $\begin{array}{l}\text { M.A., history; } \\
\text { some law school }\end{array}$ & Some college & B.S., business & B.A., accounting & $\begin{array}{l}\text { B.A., industrial } \\
\text { arts }\end{array}$ \\
\hline Farming since* & 1979 & 1971 & 1958 & $\begin{array}{l}\text { No longer } \\
\text { farming }\end{array}$ & 1982 \\
\hline Farming employment & Full-time & Part-time & Full-time & $\begin{array}{l}\text { No longer } \\
\text { farming }\end{array}$ & Part-time \\
\hline Production & $\begin{array}{l}\text { Tobacco, } \\
\text { produce, flowers }\end{array}$ & $\begin{array}{l}\text { Tobacco, } \\
\text { livestock, dairy }\end{array}$ & $\begin{array}{l}\text { Livestock, } \\
\text { produce }\end{array}$ & $\begin{array}{l}\text { No longer } \\
\text { farming }\end{array}$ & $\begin{array}{l}\text { Livestock, } \\
\text { produce }\end{array}$ \\
\hline Farming methods & $\begin{array}{l}\text { Traditional } \\
\text { (organic } \\
\text { practices, not } \\
\text { certified) }\end{array}$ & $\begin{array}{l}\text { Organic } \\
\text { (working toward } \\
\text { certification) }\end{array}$ & $\begin{array}{l}\text { Organic, confined } \\
\& \text { free range } \\
\text { (working toward } \\
\text { certification) }\end{array}$ & $\begin{array}{l}\text { No longer } \\
\text { farming }\end{array}$ & Confined \\
\hline Acreage & $\begin{array}{l}50 \text { (actively } \\
\text { farms } 3 \text { acres) }\end{array}$ & $\begin{array}{l}20 \text { (originally } \\
300 ; \text { decrease } \\
\text { was due to } \\
\text { foreclosure) }\end{array}$ & 50 & $\begin{array}{l}\text { No longer } \\
\text { farming }\end{array}$ & 145 \\
\hline Experienced foreclosure? & No & Yes & Yes & No & Yes \\
\hline $\begin{array}{l}\text { Generation in farming } \\
\text { (including sharecropping) }\end{array}$ & Second & Third & Fourth & Third & Fourth \\
\hline$\%$ income from farming & $30 \%$ & $50 \%$ & $10 \%$ & $0 \%$ & $10 \%$ \\
\hline Current employment & Farmer & $\begin{array}{l}\text { Farmer; nonprofit } \\
\text { organizer }\end{array}$ & Deceased & Retired & $\begin{array}{l}\text { Farmer; small } \\
\text { business owner }\end{array}$ \\
\hline Former employment & $\begin{array}{l}\text { City planner; } \\
\text { manual laborer; } \\
\text { factory worker; } \\
\text { pipe layer }\end{array}$ & $\begin{array}{l}\text { Farming entre- } \\
\text { preneur; life } \\
\text { insurance } \\
\text { salesperson }\end{array}$ & $\begin{array}{l}\text { Teacher; } \\
\text { salesperson }\end{array}$ & $\begin{array}{l}\text { Computer } \\
\text { programmer }\end{array}$ & Teacher; mason \\
\hline
\end{tabular}

\footnotetext{
* Reflects the year the farmer began her or his most recent operation.
} 
Figure 1. Depiction of Study Activities and Procedure using Photovoice

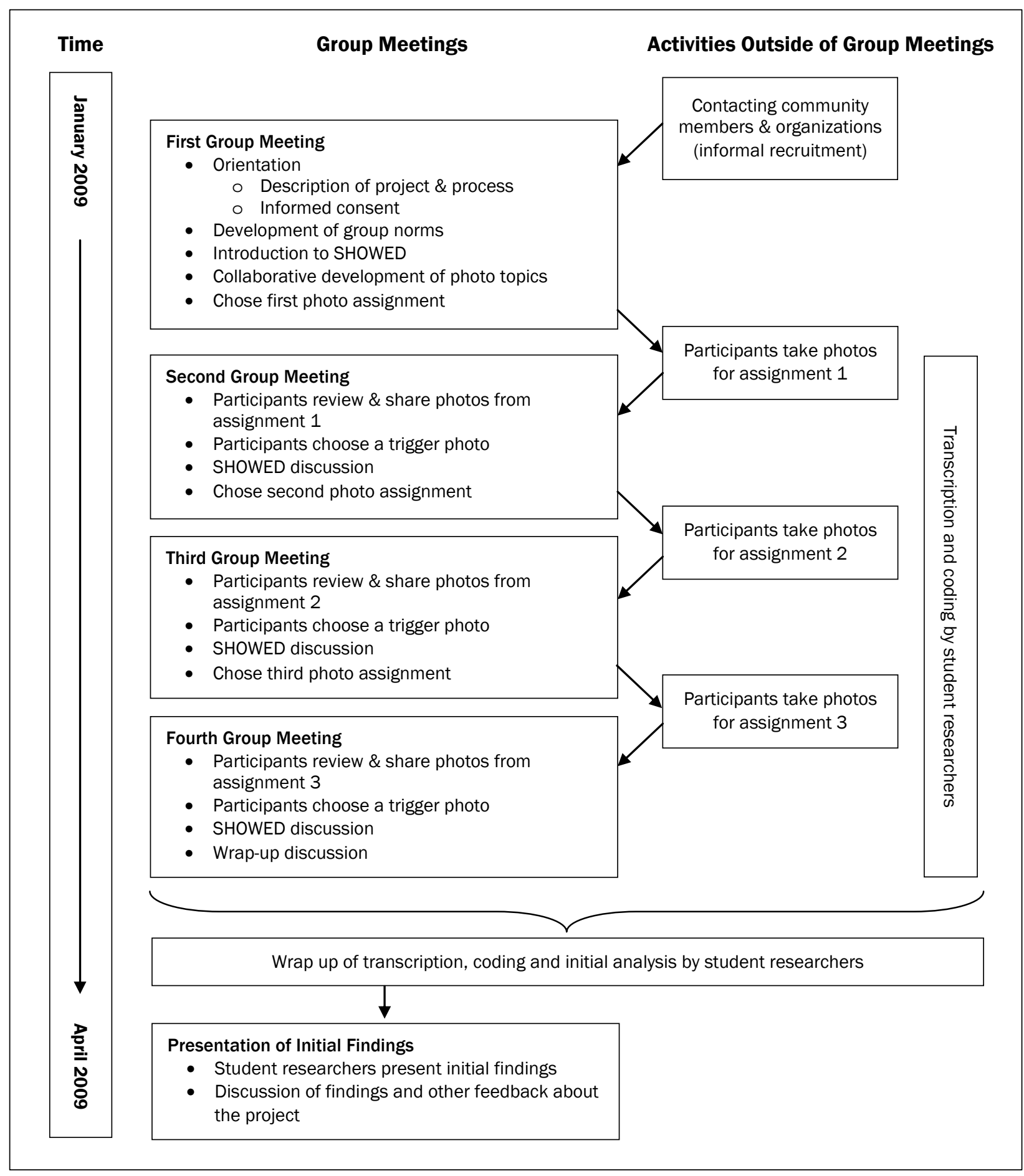

however, aims to reflect and act upon community concerns and strengths rather than make broad generalizations. According to a seminal article by Wang and Burris (1997), Photovoice has three stated goals:

(1) to enable people to record and reflect their community's strengths and concerns, (2) to 
promote critical dialogue and knowledge about important issues through large and small group discussion of photographs, and (3) to reach policymakers. (p. 560)

Photovoice and qualitative data analysis are appropriate methodologies for an inductive discovery of lived experiences (Catalani \& Minkler, 2009) and effects associated with land loss. Photovoice methods acknowledge that African American farmers are the experts of their individual and collective experience. Accordingly, an inductive discovery of their experience, the cumulative effects of land loss, and ways to address concerns in their words were sought rather than a deductive understanding of isolated concepts or indicators. Following the Photovoice process, participants were first asked to collectively develop a photography assignment relating to issues of farmland loss. Next, participants were asked to take photographs related to the topic through the week. At a follow-up meeting the group collectively selected

\section{Figure 2. Overview of SHOWED Discussion Process}

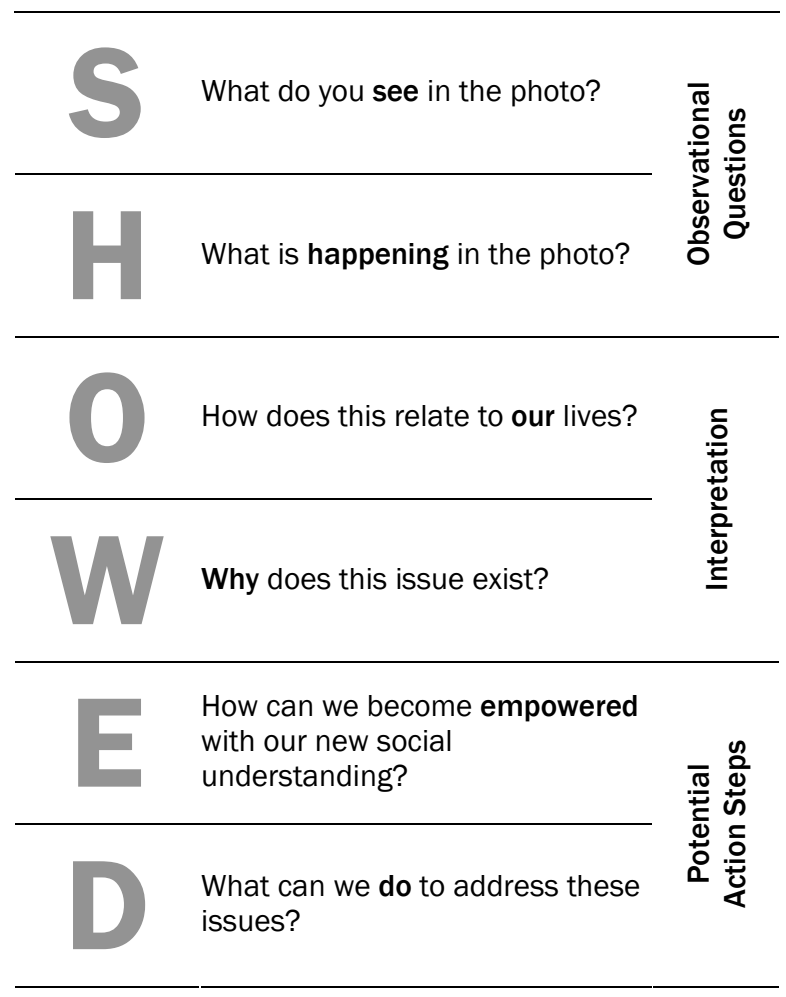

one or two photographs they believed best represented the photo assignment. The selected photos served as triggers to generate discussions and probe for deeper meaning (Wang \& RedwoodJones, 2001). This procedure was iterated through three distinct photography and discussion sessions. See figure 1 for a depiction of the procedure and timing of study activities.

Discussion sessions were facilitated using the SHOWED method, an empowerment educationbased facilitation technique, to: (1) engage participants in comparing and contrasting their individual and collective experiences, and (2) identify their strengths and concerns as farmers confronting the issue of land loss (Wang \& RedwoodJones, 2001). Using photographs as triggers, SHOWED progressively leads participants from observational questions, through interpretation, to potential action steps for addressing concerns (figure 2). Through the dialectic, individual commentary was challenged by other participants and researchers alike to cross-check legitimacy of experiences in relation to the group, and to foster a new collective understanding. With the consent of the participants and Institutional Review Board approval from the University of North CarolinaChapel Hill, all sessions were audio recorded.

Step-by-step qualitative analysis was conducted throughout the study including reading, coding, displaying, reducing, and interpreting data (Ulin, Robinson, \& Tolley, 2005). Between sessions, researchers transcribed audio recordings, reviewed content for preliminary themes, and identified gaps in understanding to be addressed at ensuing meetings. At the conclusion of the last Photovoice sessions, a final codebook with 15 codes was developed by researchers from preliminary codes and themes, including definitions and coding rules. A code is a label that is attached to a piece of text to better enable researchers to group and compare similarly labeled sections of information. For example, sections of text were coded "protective factors" when participants mentioned or referred to the benefits of farming as it relates to protecting individuals from poor health and social problems. The 15 codes were the result of iterative review of 
transcripts and researcher discussions to identify the most prevalent and rich preliminary themes.

Transcripts were double coded to ensure internal reliability using Atlas.ti software, Version 6.1.8. All sections of labeled text within each code domain were then extracted using the software, and compared to reveal patterns of meanings, or themes. For example, a theme identified under the code "protective factors" is:

Participant farmers believe farming will create a strong work ethic in youth and prevent them from becoming involved in illegal or otherwise dangerous activities.

For some codes, the patterns of meaning were not strong enough to compose a theme. For themes identified in this study, representative quotes were extracted and are presented in the findings section. Final themes were further arranged in three overarching categories. Post analysis, findings were presented to participants to check for accuracy.

\section{Findings}

Each Photovoice session provided rich qualitative data that included photo assignment selection, photography, and photo discussions. Through successive sessions, participants developed the following assignments to guide their photography and discussions:

- Why we continue to farm despite the odds

- Communities of justice and injustice

- Politics and economics

Analysis revealed several overarching categories, including historical and current discrimination, positive perceptions of farming, and farming and the next generation. For each category, associated themes, representative quotes, and photos are presented. A summary of themes within the overarching categories can be found in table 2 . Collectively developed recommendations for

\section{Table 2. Summary of Overarching Categories and Themes}

\begin{tabular}{|c|c|}
\hline Category & Themes \\
\hline $\begin{array}{l}\text { Historical and Current } \\
\text { Discrimination }\end{array}$ & $\begin{array}{l}\text { - Past discrimination resulted in participant African American farmers not trusting } \\
\text { governmental organizations and some report continued discrimination on the farm. } \\
\text { The group believed lack of access to loans has led to an increase in the financial } \\
\text { problems of African American farmers and has been a factor in the dwindling size } \\
\text { of the African American-owned farm. } \\
\text { - Discrimination increased the psychological stress of participant farmers, } \\
\text { influencing sense of self-worth. } \\
\text { - Participant farmers believe that lack of representation in governmental agencies } \\
\text { hampers advancement of African American farmers. }\end{array}$ \\
\hline Positive Perceptions of Farming & $\begin{array}{l}\text { Despite the perception of continued discrimination, participants believe } \\
\text { instrumental changes by government agencies to be more inclusive of African } \\
\text { American farmers has contributed to greater success on the farm. } \\
\text { - Participants believe lack of funding and opportunities have had the effect of } \\
\text { making African American farmers innovative and entrepreneurial to sustain their } \\
\text { farms. }\end{array}$ \\
\hline Farming and the Next Generation & $\begin{array}{l}\text { - Participants believe that farming helps them to be more self-reliant and live a } \\
\text { healthier lifestyle. } \\
\text { - Participants perceive that African American farmers continue to cultivate the land, } \\
\text { despite advancing age, with hopes to pass on the land for the next generation to } \\
\text { farm. } \\
\text { - Participant farmers believe farming will create a strong work ethic in youth and } \\
\text { prevent them from becoming involved in illegal or otherwise dangerous activities. } \\
\text { - Participant farmers believe that African American youth avoid farming because of } \\
\text { the financial and emotional struggles they witnessed while growing up, and are } \\
\text { lured by activities that generate more money at a faster pace. }\end{array}$ \\
\hline
\end{tabular}


preserving African American-owned farmland were also discussed and recorded at each session. These recommendations are presented at the conclusion of the findings section.

\section{Historical and Current Discrimination}

Race-related discriminatory lending practices on the part of the USDA remained a present and pressing concern for participants. Themes identified as related to discriminatory practices were both historical and current (see table 2). Reported experiences of historic discrimination or witnessing this on other African American farmers permeated every session. Many of the participants reported actively fighting systemic race-related discrimination for decades, both within North Carolina and in Washington, DC. One participant, who has farmed in North Carolina since 1958, recalled the history this way:

What Black farmers have encountered over the years is basic, hard racism - Black lawsuit [Pigford v. Glickman], out of Washington DC, because of misjustice. People weren't treated right.

All participants agreed that disparities in lending during the previous decades strongly deterred African American farmers in their community from applying for needed loans from the USDA. Instead, farmers sought out local creditors for small loans, or managed with what they had, until they depleted personal savings. One participant who continues to farm the same tract of family land he helped with 50 years ago recalled the experience within his community:

In fact they [African American farmers] wouldn't deal with loan officers because they know it wouldn't come out in their favor. Instead, it's better just to do what you can, because once you start dealing with the loan officers, they're gonna make it difficult for you....And they'll use everything they can to prevent you from getting the loan, and then they'll get you in a situation where you've gone so far and then they start now giving you problems with taking your property.
The absence of access to adequate credit resulted in minimal reinvestment into the farm. Participants acknowledged that regardless of the race of the owner, small farms are at an economic disadvantage primarily due to economies of scale: small farms' owners receive smaller subsidies; often have less access to major markets because of smaller yields; and have limited buying power due to smaller revenue streams. The added effect of discrimination through compromised loan access was viewed as further restricting development into larger operations. One participant expanded, providing a current example on how having a smaller farm put her family at a competitive disadvantage:

Well, one thing was that fuel got so high [expensive], and you had to keep your farm fuel, you know... If you're a small farmer and you can't afford but a hundred gallons at a time, ah, in the past, maybe you'd buy a hundred gallons, used it up, paid, and buy another hundred gallons. But then all of a sudden, even for small farmers you'd have [to purchase] a minimum of two hundred gallons [at a time].

Beyond restricting economic advancement, discriminatory lending had the effect of making some of the participants feel as if they were incompetent farmers and, as a result, increased their experiences of stress. In addition to receiving less money from loans, one participant recalled waiting with other African American farmers in lending offices entire days while White farmers came and went. The psychological effect of this was often significant, as exemplified by the farmer who once believed the disparities in lending were a reflection of his abilities, despite later traveling widely to share his farming expertise. He explains the effect of discrimination this way:

It takes you to these places, places you don't even want to go [feelings of depression and lack of selfworth], when they treat you like this...And, ah, you know, it's these types of things that we've experienced all our lives. I thought that I was the bad part: well, you know, I'm just no good. But when the lawsuit [Pigford v. Glickman] came to be, 
and I saw these hundreds and hundreds of people come in, I said, "Well, I'm not gonna be by myself, and we all can't be bad farmers." So then it was the establishment that put us where we are.

Throughout the discussion, participants agreed that discrimination endured by African Americans in their community deteriorated self-confidence, which prevented them from seeking new opportunities for economic advancement since they expected further rejection. According to the participants, many farming colleagues began to despair about their opportunities within agriculture. This is illustrated by the following quote:

And if I tell you "no" long enough, you're going to believe "no." And that's what has happened to a lot of the older folk in the neighborhood, you know, they've been told no, no, no, so much that they just accept a negative attitude.

Among African American farmers in the region that remain in the profession, many were noted to have withdrawn from participating both in educational and financial meetings, and the wider community of farmers. Participants attributed this absence to both historic discrimination causing distrust of government institutions, and competing time demands to earn a living. One participant offered his opinion:

Black farmers are very shy. We are in bad shape and we don't want anyone to know it-not anyone.

For another participant the distrust pointed to a need for yet further reform to deal with what he perceived to be the persisting underlying problem. He commented:

The nation needs to know that we haven't eradicated racism. It's been going on, and it needs to be eliminated.

A couple participants lamented the lack of African American representation in government positions to influence reform, and reported continued experiences with discrimination today. Among
African Americans employed in farm-related government positions, many were believed to be occupying token posts. A participant who is active in community outreach and continues to regularly attend USDA-sponsored meetings explained:

We...don't have the people that are in places in NC [North Carolina] that would help the majority of the small Black communities to pull themselves up by their bootstraps. Some people may disagree..., but I know people who are really trying. And it seems like every time they try, there's somebody out there to put their foot on their head, to pop up this way, they gonna push 'em down in another place. And, it's NC [North Carolina] politics.

Another participant noted disparities in land use conservation enforcement on his farm compared to his White neighbor. For the photo assignment "Politics and economics" this participant took a photograph of a fenced-in stream on his neighbor's land where cows were allowed to roam (photo 1). While another participant referred to environmental regulations restricting farm animals from wading into interconnecting bodies of water, the photographer reported his experience as inconsistent with what is required of the White neighbor:

It's a branch [stream], right down through the middle of it [land]. Now my thing, how come he [White farmer] can allow his cows to run in the branch, and they made me fence mine out. So my animals, my hogs, couldn't get in it [stream].

Experienced and perceived discrimination has resulted in a continued distrust of some agriculture-related governmental agencies, as noted in the above quote. The initiation of the Tobacco Transition Payment Program in 2005 (commonly referred to as the "tobacco buy-out") was viewed by some participants as a means to eliminate smallscale African American farms. Most participants recalled that, even before the start of the program, the amounts of tobacco they were contracted to sell, as well as selling prices, became progressively lower compared to that of White farmers. One 


\section{Photo 1. Fenced-In Stream Running Through a Cow Pasture on a White-Owned Farm}

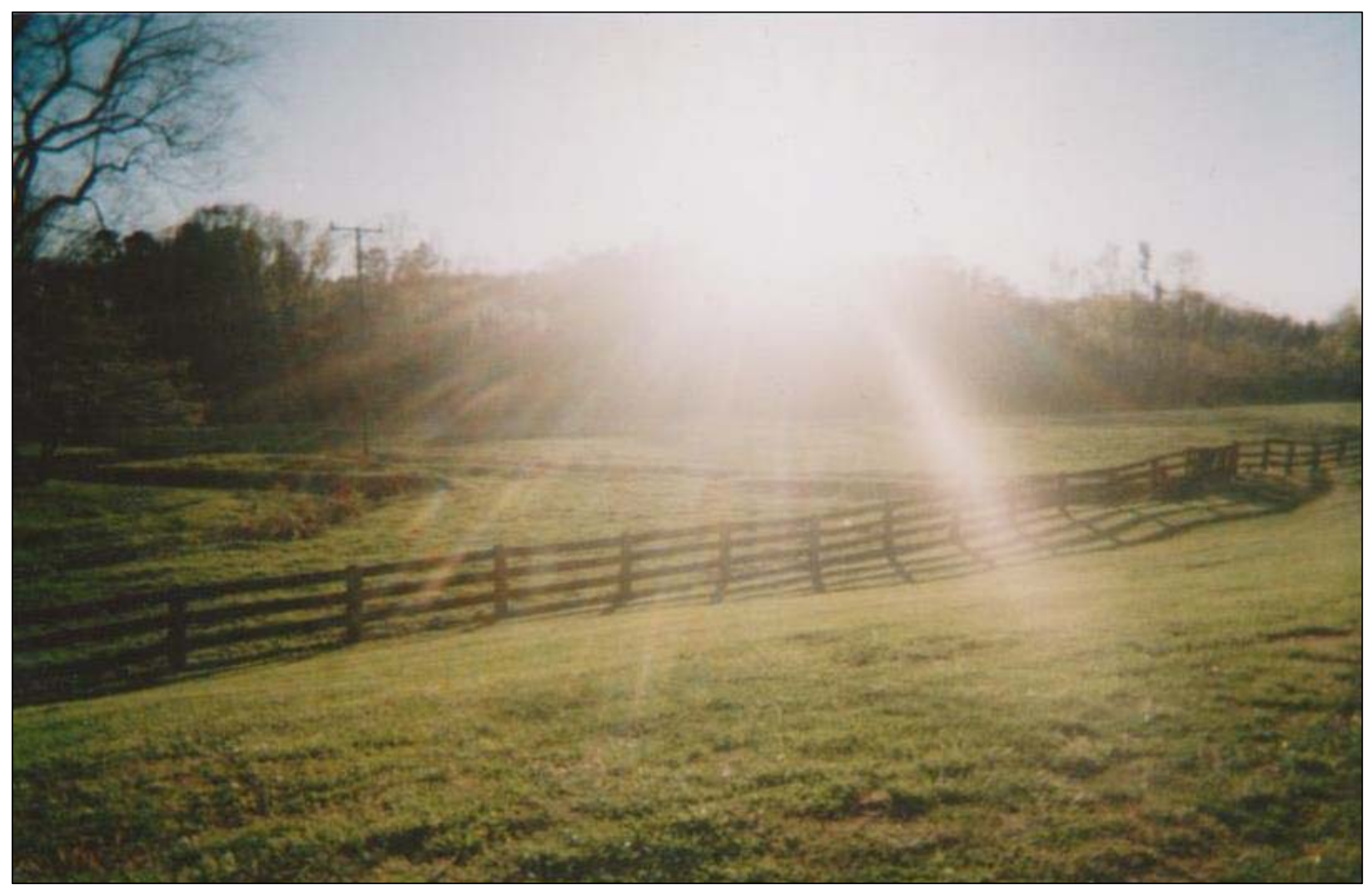

Photo credit: Photovoice participant.

participant viewed the transition program this way:

The tobacco buyout to me, was, one of those strategies that would eliminate the one-acre, the two-acre, the five-acre smaller Black farmers, and to get his acreage so that they [larger farms] could become bigger. And so they came up and made a rule that we gonna have a tobacco buyout....You [government agencies and large farmers] have stolen for so many years—grandma, this lady's poundage [tobacco quota], that poundage....But to get them [eliminate small farms] complete.

In addition to distrust, the low incomes generated from small-scale farms force owners to continue maintaining supplemental employment, thus reducing the time farmers have available to attend USDA-sponsored and other farm-related meetings. Due to these competing demands African American farmers are underrepresented at those meetings, and, consequently, their concerns are not heard or addressed. In light of these significant barriers faced by African American farmers in their communities, an outreach advocate within the group explained:

They'll [government agents] say "oh they're [African American farmers] not here." Well, what you talking, why they not here, because they cannot make every place that they need to be....If you don't have enough gas to carry you to work every day, how can you afford to leave from [town], go to work, come back, or go to work and leave from work, go to Raleigh to attend meetings, so?

\section{Positive Perceptions of Farming}

Despite years of reported discrimination, study participants remain involved in farming. They were excited to highlight success stories conveying what they and other African American farmers have at- 
tained through ingenuity, persistence, and collective organization. Themes identified through analysis of participants' discussions on their positive perceptions of farming can be reviewed in table 2 .

All participants reported disparities in Farm Service Agency (FSA) loan amounts and timely disbursement between White and African American farmers, but reacted differently. With compromised access to larger FSA loans, most farmers relied on local creditors and merchants in their community for support. While one participant recalled his family's approach to be conservative and borrow as little as possible to get by, two others would seek to maximize investment in their land. Another participant successfully used available resources to supplement funds by starting a small organic fertilizer business, as she commented:

I was told that I was full of it, never [fit] to be a seller. I sold more manure - cow, pig, more money....We had to, we didn't know about biodiesel then. We had to have money for gasoline and diesel fuel for the fields.

Participants recalled how they were compelled to be entrepreneurial to remain as farmers. Almost all farmers either held another form of employment or started small businesses to survive financially. While all participants recognized this struggle to be a common plight for small farm owners regardless of race, discrimination was viewed as an added barrier to successful farming. The group discussed how disparities in lending forced them to be innovative in maintaining equipment while their White counterparts purchased new technologies. As recalled by one participant:

One of the FSA loan officers told us in the past "Use it up, fix it up, do anything, don't buy anything new." We couldn't go out and get this piece of equipment new.

The ingenuity participants mentioned as imperative for their survival as farmers in the past is seen to have an additive effect when eventually given more equal access to funds and opportunities. Farmers selected photo 2, a biodiesel machine, as a trigger to represent this innovation of African American farmers. One participant commented on the African American farmer in his community that built the machine after successfully competing for funds through the FSA:

He can take nothing and make something out of it.

\section{Photo 2. Machine Used To Make Biodiesel on an African American-Owned Farm}

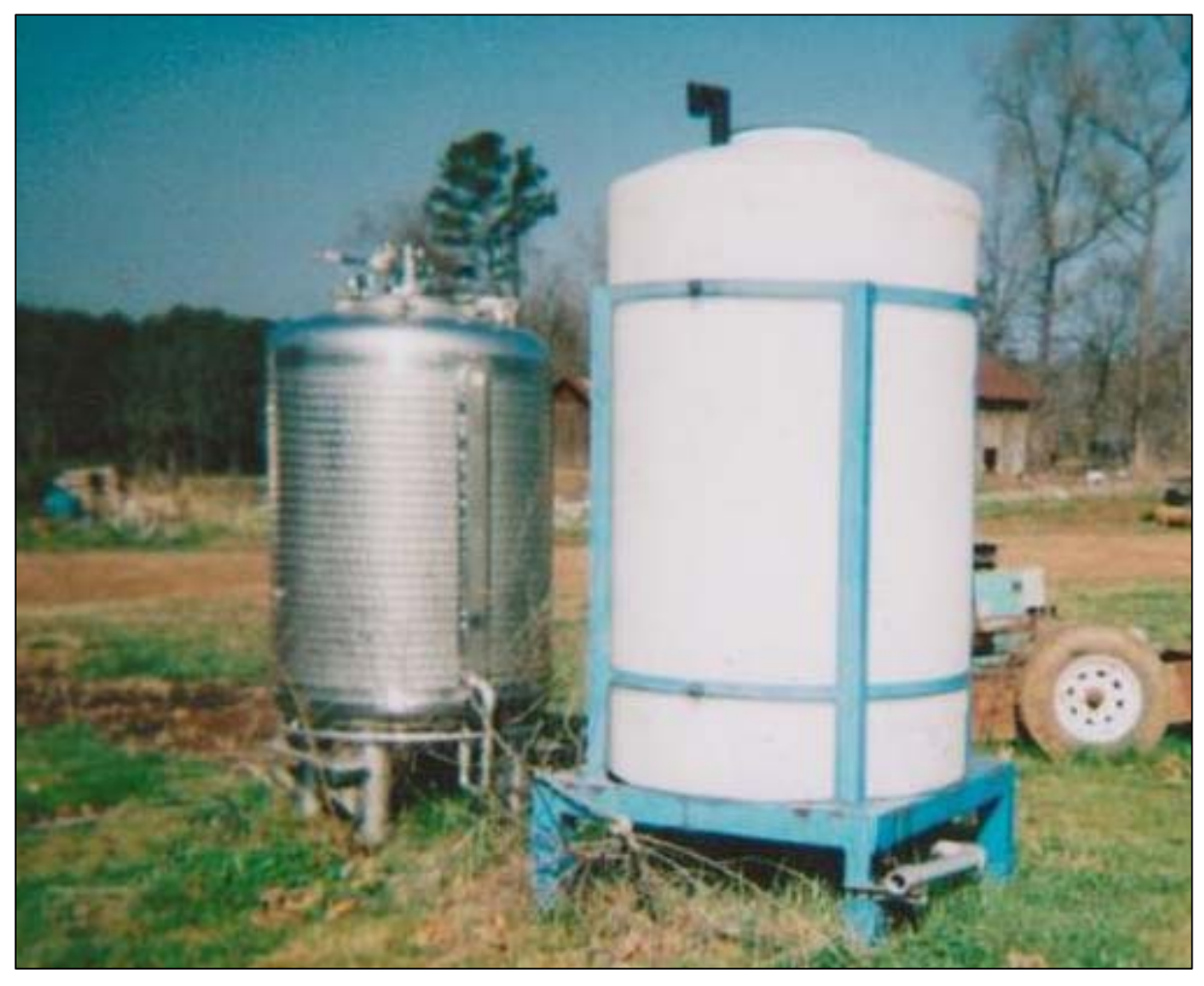

Photo credit: Photovoice participant. 
[He] took it, and he's talking about right now incorporating it with some bigger tanks to make more fuel. And he wants to get to the point where he can commercially sell it, you know. Right now he doesn't make that much, he just does enough for his farm and enough for demonstrations.

As evidenced by the biodiesel machine, the participants strive to be current with emerging agricultural innovations and the changing demands of the market. All participants have taken steps to become certified as organic, discussed at length sustainable practices, and one had recently started preparing free-range lots for livestock in lieu of confinement operations. During discussion on the same topic, participants also noted the success another African American farmer in the state has had in raising turkeys (photo 3), along with other animals and crops, for a decent profit. The creativity with which the farmer approached raising and marketing these turkeys demonstrates the entrepreneurial spirit that garnered a state award for farming excellence. The participant who took this picture interpreted the photo in the frame of justice: ability to produce food and provide for their families, a heightened concern in light of the country's insecure economy at the time this study took place. Participants also felt that by farming one could maintain health through the physical activity of working in the fields and by eating the healthy food produced. A participant who raises livestock and vegetables reported on the security farming can provide:

We can feed ourselves, and no matter how bad the economy gets, regardless of what anybody else does. All farmers know how to provide enough food to feed their family. That's a necessity.

The farmers also shared the common excitement of watching growth-whether it be livestock, produce (shown in photo 4), or the burgeoning future of African American farmers in their community. All participants spoke positively about how farming fostered creativity, allowed them to work in the fresh air, and offered different challenges and opportunities with each new day. Such sentiments inspired one participant to invest in the community by developing a town market
And this one I picked from when we went on a farm tour, and I picked that as justice - you know, showing where we [African American farmers] were able to do some things with some help from some grants and some other justice. To me, that's instrumental changes.

All participants agreed that the positive opportunities provided by farming outweighed the difficulties faced. Farming increased their self-reliance and their

\section{Photo 3. Farmers Walking Past Turkeys Being Raised on an African American-Owned Farm}

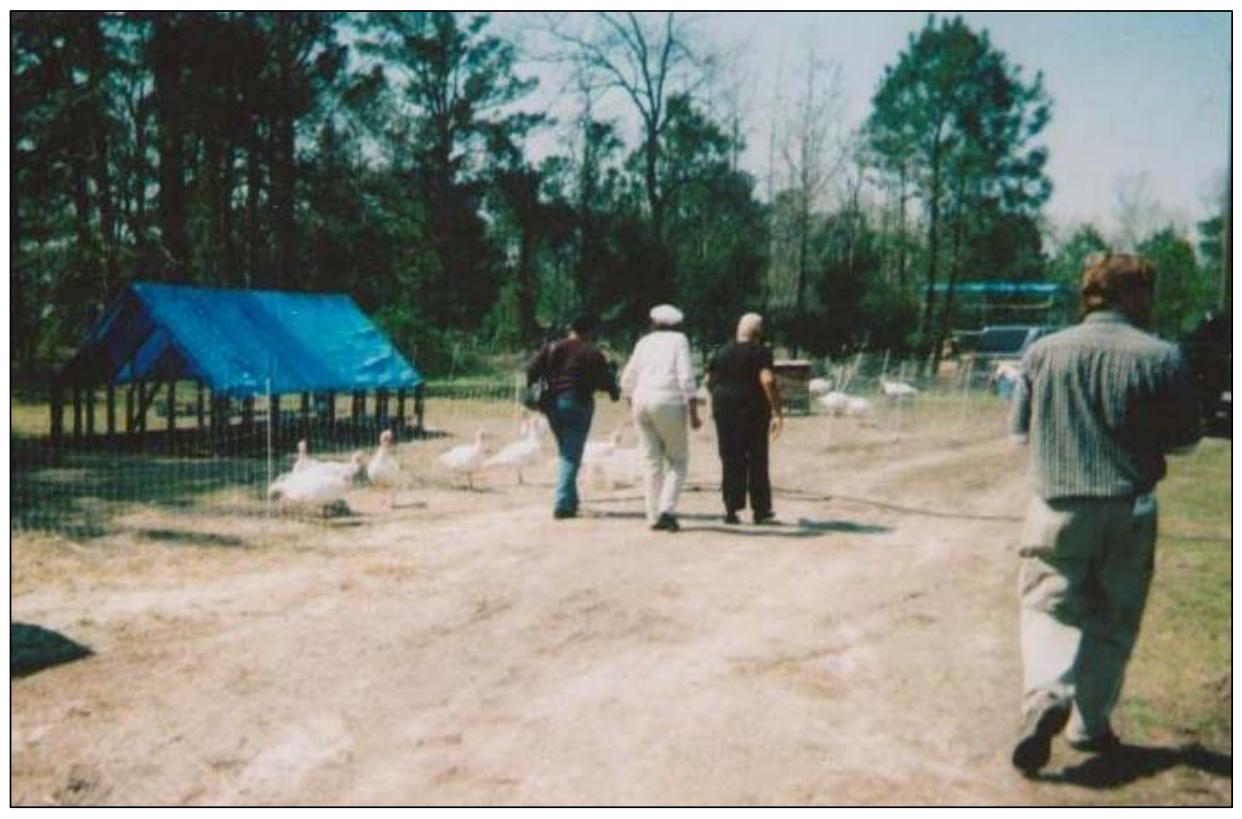

Photo credit: Photovoice participant. 
wherein he sells produce from local farms and crafts alongside the meat from his hog farm. He commented:

\section{All farmers enjoy seeing things develop and grow. I mean that's really what we get excited about.}

\section{Farming and the}

Next Generation

Every farmer participating in this study underscored the importance of involving African American youth in farming. Engaging the next generation in farming was a prominent discussion under the topic "Why we continue to farm despite the odds." See table 2 for themes identified through analysis related to Farming and the Next Generation.

Many participants reported that they farmed primarily to ensure that they could pass on their land and profession to their children or grandchildren. A couple of the farmers discussed with regret how they had missed the opportunity to recruit their children to eventually take over the farm while they worked in other professions, or before they came to own the family

\section{Photo 4. Field of Spring Greens Growing on an African American-Owned Farm}

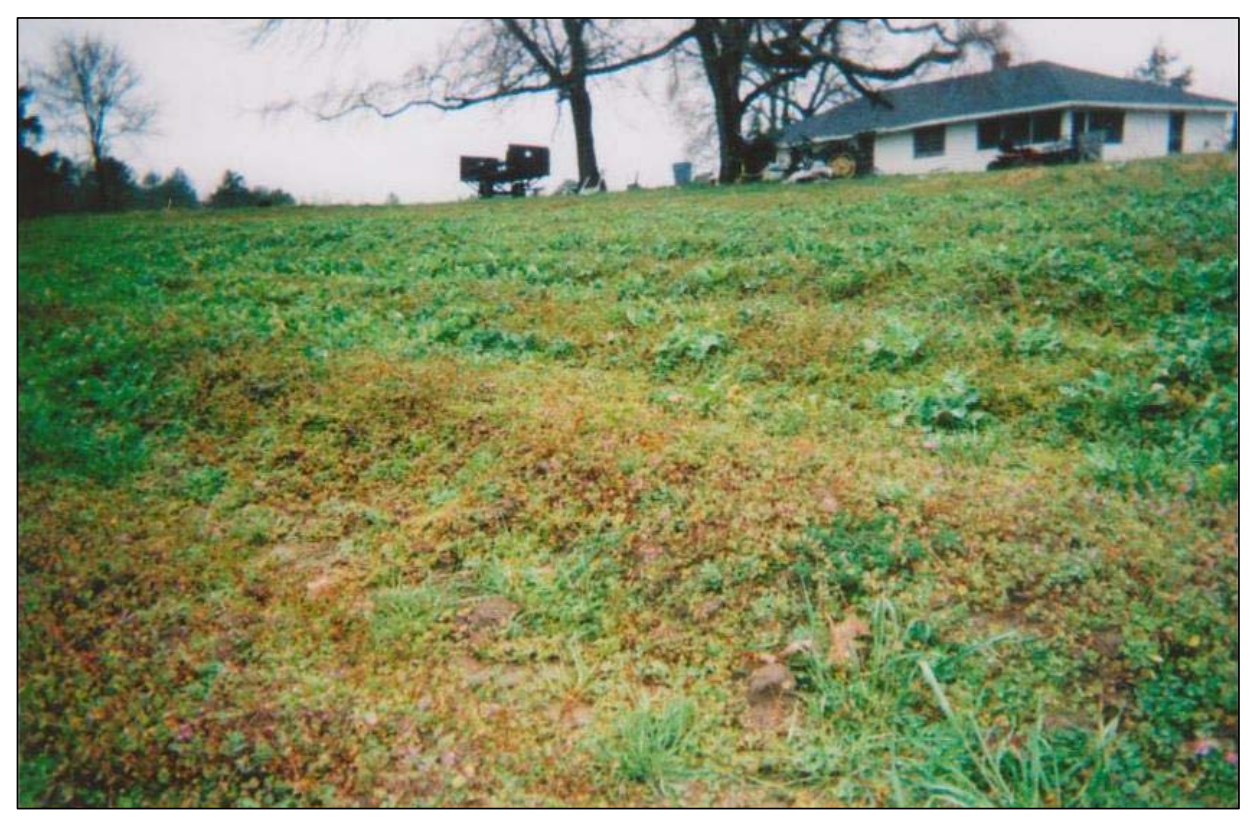

Photo credit: Photovoice participant.

\section{Photo 5. Grandchild of a Study Participant Walking Off the Back of a Truck To Help on the Farm}

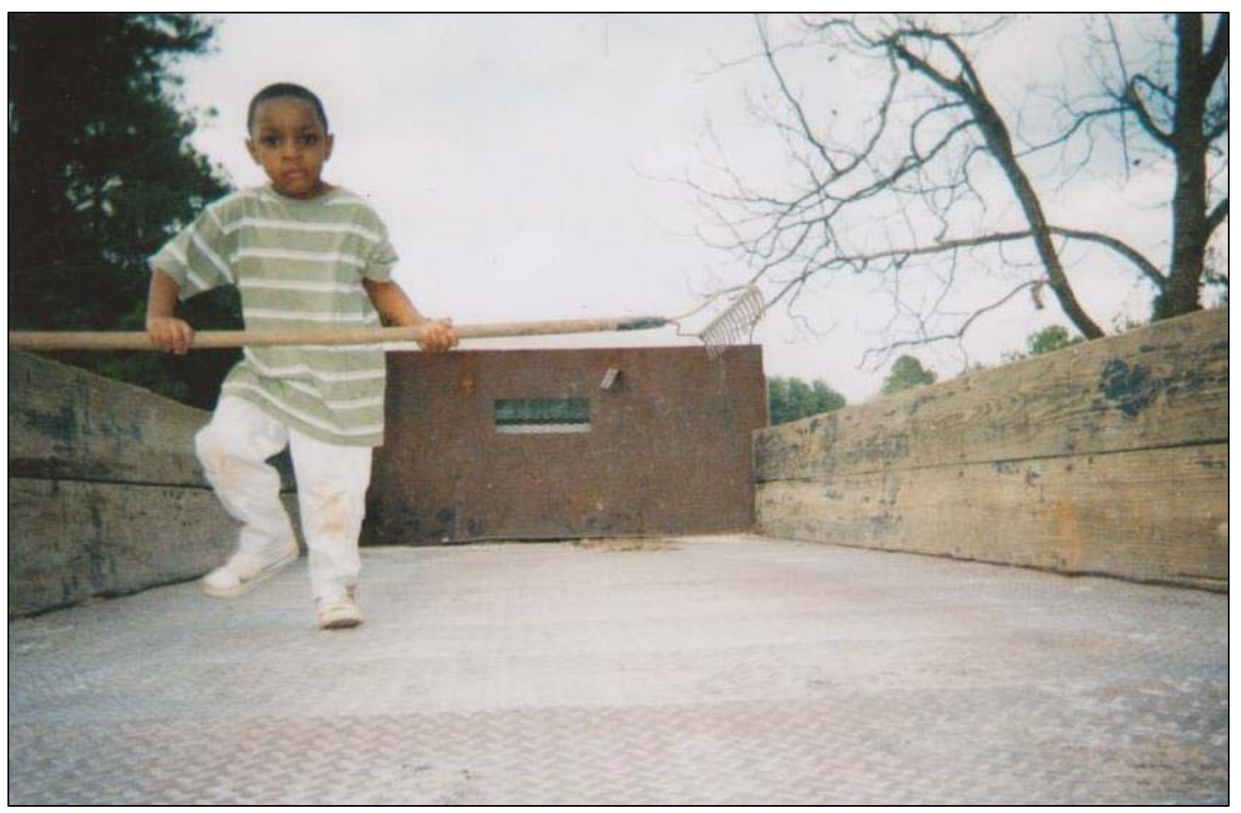

Photo credit: Photovoice participant. farm outright. As a result, they see the need to mentor their grandchildren and other youth so as not to miss another generation. A participant who 
was successful in cultivating a desire to farm in his four-year old grandson explained the strong emphasis he puts on passing along the value of farming (photo 5):

I'm doing it basically for my grandchildren because I want them to continue being able to live the goodness. And I'm teaching him [grandson].

Another participant who successfully involved both her grandchildren and other African American youth in farm work elaborated:

If he has the choice he is out there on that farm with this grandfather. [He] doesn't have to worry about anyone messing with him, not contained, as long as he is outside. Living in the city he couldn't go outside and play peacefully. Farm life is better for him. If we can hold them to the land maybe one day they can make a profit. The next generation, that's why we continue to do what we do.

All participants vocalized their concern about the loss of family land outright and the need to provide youth with healthy lifestyle options as reasons to continue farming. Getting youth involved in farming was viewed as a way to build a strong work ethic, to promote physical and mental development, and, as a protective factor, to keep children away from damaging activities like the use and sale of drugs. Concern that the next generation is being attracted to selling drugs and other crimes to make money prompted one participant to start a youth gardening program to cultivate interest in farming. In commenting on the photo of the young boy in photo 5 , this participant relayed hopes and fears for the younger generation in relation to farming:

I see a little boy on a truck. That's what I want to see - more people off the streets and on the farm doing something constructive. That's what I hope to see - more kids off the street and it's hard.

Continuing the legacy of farming family land was important to the participants and is currently a pressing concern because of the aging African American farmer population as a whole. A majority of participants are retired from their other jobs and are able to devote much of their time to farmrelated activities. An older participant who cultivates vegetables with his brother repeatedly commented on the need and benefit of involving young people in farming:

As I said, the young people are out there, and they got the great minds....I'm an old man, and they got the minds.

This participant recalled that a couple of decades ago it was commonplace for young African Americans in their community to seek work on the land. During that time, the children sought farm work to earn money to buy materials and new clothes for the first day of school. Farmers did not have to seek help from the youth; youth sought out the farmers. The trend of African American youth involvement on farms in the region has been decreasing, however, as he explained:

Well my brother he was here for two generations; he was hiring young youth, but within the last [20 years] things were slowing. He hired a lot of youth. If we were to have a thriving produce business we could have brought some of the younger kids into this kind of operation. So for 20 years in this community we have had very little impact on a generation of youth. And previously we had a lot of impact.

Participants discussed how economic influences deter youth from going into farming as a profession. They highlighted two deterrents: (1) the effect of watching parents struggle financially with farming, and (2) the lure of fast money from selling drugs as an alternative to a lifetime of struggle on the farm. This is described in the following statements:

I think young people my age and a little younger saw their parents work a lifetime, and then got to check-up at the end of the year [with the owner of the farm, usually White], "you're almost paid up this time, John." Gotta work a whole year for that farmer [as a sharecropper], and when that White man paid [you] at the end of the year, you almost made out [paid off your expenses]. Means you got 
to work another year, you know, go buy shoes for your children, you have to go to that man to borrow money, because he [the African American farmer] don't got any of his own.

Well like I said, they [children] see there's not any success in his father's farm, so why would he want to go down and be a farmer, and do the same thing his dad did and be a slave the whole time.

And I can understand why I see children now or boys on the corner selling drugs. Because they see the guy driving down the street, and that looks nice, all that gold around his neck, and got a roll full of money. He doesn't understand the consequences, but for work on that farm, ten dollars - no, five dollars an hour, you can't but make 50 dollars. Five days a week that's 250 dollars, and that boy can stand on the street corner, and in an hour have a wad big enough to choke a horse. And that's what they want, they want some of the finer things, and you aren't gonna get it from a farm.

One of the participants warned that the memory of discrimination believed to deter African American children from farming will have further negative ramifications for the nation as a whole:

I think the nation, when the nation fails, I would hope that they would have enough foresight to realize the importance of the Black farmer before they fail miserable. Because they [the United States] are inevitably on a road of failure, because as I said, they have excluded - maybe not openly, but by not opening the doors of opportunity to young people they have cut off some of the most talented and great minds that could really shape agriculture and deal with the challenges there.

Although the participants reflected that youth in the community are more inclined to pursue other jobs than work on a family farm, they also mentioned that African American farmers held onto their land, regardless, in the hopes of maintaining their heritage. Many had doubts as to whether the individual(s) who ultimately inherit the land will continue with the profession. One participant reported on the continuing trend of children not farming inherited land:

When you deal with people holding on to their land.... They pay taxes on this land and a lot of them will not sell it because they say they want to keep it in the family. And that's where I think this is going to. People are keeping land in the family because they have so many memories of it. But as to people getting out [in the fields] and growing stuff, it's a new day [not happening].

\section{Participant Recommendations to Address Land Loss} As noted above, the methods employed in this study include a process for participant-developed action steps to support African American farming in their communities. Collectively developed participant recommendations for addressing issues around farm or acreage loss are summarized in table 3 .

The participants had already taken steps to retain their land and that of other minority farmers through individual initiative and participation in outreach through nongovernmental organizations. Farmers noted that the general public, however, is largely unaware of the history and issues surrounding the disproportionately high rate of farmland loss by African American farmers. One participant

\section{Table 3. Participant-Recommended Actions to} Preserve African American-Owned Farmland

\section{Action Steps to Address Land Loss}

- Continue to raise awareness in public and among government officials about injustices that affect African American farmers.

- Promote collective organization and cultivate leadership by engaging the community, including farmers and nonfarmers, through outreach activities.

- Facilitate ongoing agricultural education in farming communities.

- Pursue funds to develop infrastructure and enable greater benefit from farming education.

- Enlist youth involvement in farming activities.

- Provide greater access to Internet services to enhance communication efforts and accessibility to information resources. 
recommended that the public and government officials be better informed:

We have to continue to bring about awareness about the injustice that goes on. We have talked to people all the way to Washington, DC. Even having no minority loan officers! Come on. People that are in authority that can do something about these injustices. But nobody applies, no one is qualified. The agencies treat them [African American employees] so bad and they won't go back. We have to make the people in authority aware.

Several participants regularly engaged in outreach efforts to inform current African American farmers about financial and educational opportunities, and to educate nonfarmers about the potential in farming. Some participants recommended that African American churches serve as venues for these discussions because these churches are the primary social outlet for the African American community. Others, however, lamented the limited amount of time available for such a discussion during services and noted the importance of expanding outreach efforts and venues. One participant had already mobilized a group to meet regularly and discuss relevant issues within the community, at which he invited professionals from across the state to speak on specific agricultural topics. He recommended further education:

I am back to education. People have become complacent. They are used to nothing, want nothing. Let the White man feed you. You can't live on Social Security. Instead of watching "As the World Turns," watch them flowers grow. Give them an opportunity.

Most of the participants have mobilized groups of children or adults to promote farming, either currently or in the past. All recognized that the progress they have made as farmers was bolstered by organization and teamwork. They recommended the implementation of collective initiatives to get other community members involved, as this quote illustrates:
One person being able to achieve is nothing. We have to organize and put our resources together. The loan thing [reparations] isn't about fixing things. I think opportunities, we have to grab opportunities. We need organization, leadership.

Participants also believed that widespread access to the Internet would facilitate better communication and access to resources. At present, Internet connectivity in the participants' communities is limited and is particularly poor for African American farmers. One farmer commented on the limited Internet service in the region:

Where I live, about a mile from me, another member, she has broadband. But when I try to get [it] they tell me we don't have a substation in your area, so we can't offer you broadband. So I have to pay like \$69 a month for wireless, you know, and I really want [Internet access] to follow me wherever I go. So, they put a lot of money in the stimulus package for new technology in areas, but, ah, and that's politics. We don't know because we're cut off. And they say, oh you all don't have cable? Yeah, the one we pulled across the yard.

Farmers agree that with affordable Internet access they could remain up to date on the latest agricultural regulations and funding opportunities, organize more people with less effort, and develop new markets for their products.

\section{Discussion}

Significant changes have been made to reduce disparities in access to government support for African American farmers (Cowan \& Feder, 2010; NCDA\&CS, 2011; USDA, 2003; USDA-FSA, 2007). As a result, farmers in this study note specific benefits that have aided in the viability of African American-owned farms in their region. According to participants this has included increased access to funding, knowledge of new opportunities, and availability of education. 2007 Agriculture Census data indicates that, from 1997 to 2007 , there was a concurrent and comparable increase in the number of African American and White farm owners $(10 \%$ vs. $11 \%)$ in North Carolina (USDA, 2009b). Gilbert, Sharp \& Felin 
(2002) claim, however, that this increase is misleading as the census changed hands from the Department of Commerce's Bureau of the Census to the USDA. These authors suggest that the new census was more accurate and inclusive of all farmer numbers, and that if the same census had been employed in the previous cycle, a continued drop in the number of African American farmers would likely have been observed. Despite advancements in federal and state programs to be more inclusive of African American farmers, participants in this study still report discriminatory practices.

The negative impacts of institutional racism, including discriminatory lending, are evident in this study and the literature (Brondolo, et al., 2009; Jones, 2000; Paradies, 2006). These findings support prior studies showing that African American farmers who continue farming also continue to endure the negative economic repercussions of years without adequate loans to invest in their farms and the resulting accumulation of stress (Hinson \& Robinson, 2008). The cyclical effect of discriminatory lending in the past affects current investment capacity, and thus wealth of these farmers, and remains a threat for the viability of African American-owned farms today.

Despite the obstacles, the participants reported continued commitment to the profession, noting that the health benefits of outdoor physical labor, producing nutritious food, and the pure enjoyment of facilitating growth enhance their quality of life. Their experiences have had the positive effect of fostering creativity and innovation on the farm as evidenced by the expansion into alternative fuel sources, the raising of free-range turkeys and other livestock, and the cultivation of new cash crops. Such innovations are seen as necessary for the survival of the African American-owned agribusiness and can contribute to the wealth and broader investment of the farmers (Gilbert, Sharp, \& Felin, 2002; Grim, 1995). Further, small-scale farm owners, like the participants in this study, contribute positively to agribusiness, and promote community vitality through the consumer industries created (Brown, Christy, \& Gebremedhin, 1994).
The participants in this study yearn to pass on their farmland and what they view as the "good life" to the next generation. To these farmers, the land represents their families' heritage and future opportunities, even with the complex challenges they have experienced as farmers. In addition to the personal pride and quality of life noted by participants, land ownership is associated with the positive educational achievement of children (Gilbert, Sharp, \& Felin, 2002), which is a primary goal for participants. It is critically important to participants that the next generation remain involved with the land to ensure survival of their heritage and to influence their well being. However, participants expressed deep concern that younger family members would choose to step away from farming and the family land because they have become disillusioned by watching their parents' financial struggles with farming and their experiences of discrimination. Participants fear that instead of farming, the African American youth who represent the next generation will succumb to the lure of risky or illegal ways to earn money that have a more immediate payout. These concerns suggest a need for innovative agricultural programs to engage African American youth.

Numerous studies on the topic of African American farmers confronting land loss make recommendations to maintain the land (Gilbert, Sharp, \& Felin, 2002; Grim, 1995; Wood \& Gilbert, 2000). Using CBPR methodology, we sought current participant perceptions on action steps believed to help curb land loss and promote farming among African Americans in their community. Primary recommendations included raising awareness of injustices affecting African American farmers, collective organization and leadership, greater access to agricultural education, funds for infrastructure development, greater Internet access, and youth involvement. Participants believed such actions will bolster success among African American farmers in North Carolina and beyond.

Based on participant recommendations, we emphasize three immediate action steps to support African American landownership in the region: 
improved access to the Internet, increased local representation, and innovative youth farming programs. Expanding Internet connectivity to the farmers' communities would enable access to current information on the latest education and opportunities. Nationwide only $34 \%$ of African American-operated farms have Internet access, compared with $57 \%$ of all farms (USDA, 2009a). Results of this study also suggest the need for increased training of African American agricultural educators and lending agents with deployment to localized communities. These services could reach a broader population if delivered at varied and nontraditional times to the schedules of farmers who also work off the farm. Finally, innovative programs involving youth in farming programs could influence future interest in the profession. Programs exist in a limited scope within participants' communities, but are starting to expand. Entrepreneurial programs that offer income through individual, community supported agriculture (CSA), or farmers' market sales may encourage youth involvement.

\section{Lessons Learned}

The procedure used to conduct this study led to numerous opportunities for lessons learned, particularly around recruitment and use of the Photovoice process. Recruiting farmers to participate in this study proved difficult. Having little experience initially with the African American farming community, we had no credentials to lend legitimacy to the project. At the outset, we enlisted the help of individuals and organizations who had connections with African American farmer networks in nearby communities and farmers' markets. Through discussions with farmers it became clear that experiences with discrimination, long distance between individual farms, overexposure to researchers, and the small numbers of African American farmers in the area would make recruitment challenging.

During recruitment, we became aware of how our race and class, current and past race relations, and the history of studies done on African American communities worked against us - a team of one African American female, three White females, and one White male. We were graduate students, younger than the age of potential participants, and represented a large research-intensive institution. As public health researchers, we were aware of the long-standing history of African American involvement in research, particularly the Tuskegee Public Health Service syphilis study. Recognizing this harmful history and the potential for distrust in the community necessitated the use of sensitivity on our part when approaching African American farmers and introducing the idea for this project. Access to participants was eventually gained through personal validation by a member of the African American farming community who was involved in efforts to maintain African Americanowned farms in the United States. Securing a foothold in the community through this gatekeeper proved essential for recruitment.

In addition to difficulties with recruitment, the demands of farming hampered the study's flow and required constant flexibility on the part of the research team. Participants were preoccupied with work and family responsibilities, preventing some from attending every meeting. Working around farm schedules proved especially difficult during the spring planting season. Following the SHOWED method directly also proved difficult: rather than following the sequential procedure leading from observation, to interpretation, relevance to the lives of the participants, and action steps, the conversations moved back and forth across these categories. Participants often combined observations and interpretations. Periodically the conversation would be brought back to the prescribed question, but, on some occasions, we thought it best not to adhere to the linear questioning in favor of allowing rich conversations to unfold.

\section{Limitations and Strengths}

The approach used in this study, including the Photovoice technique, has its weaknesses. The small sample sizes of qualitative analysis and convenience sampling do not support broad generalizations across the population. The aim of this project was to capture the strengths and concerns of African American farmers in a North 
Carolina community in light of historic discrimination and its effect on land ownership. While prior research reveals that discrimination and issues of farmland loss are widespread in the region and it is expected that other African American farmers in the American South may have similar experiences, the specific events and histories related here are unique to these participants.

Photovoice also has strengths. This method allowed us to gain input directly from individuals affected by discriminatory lending. Further, Photovoice taps into the rich traditions, history, and strengths of community members regardless of their educational background. Additionally, the use of Photovoice engaged all participants in finding connections between the lived experiences of each group member, and brought a strong sense of context and place to each discussion. The use of photographs as triggers aided participants' efforts to convey these experiences not only in their own words but also from their own perspectives.

Finally, the iterative research process of Photovoice, with its series of meetings and opportunities for exchange and co-learning, allowed participants and researchers to build rapport and probe difficult issues. Participants were not shy about sharing personal trials, but as the collective level of comfort grew, the discussions and the topics explored deepened. Later conversations allowed all group members, participants and researchers alike, to gain deeper understanding of the challenges faced by African American farmers in this region. Moreover, the Photovoice method created the opportunity for the farmers to explore their experiences in a new light, share those experiences with influential advocates, and generate next steps to address their concerns.

\section{Conclusion}

This study illustrates the lived experiences of five African American farmers in North Carolina, their experiences with discrimination, and their farming successes despite that discrimination, in their own words. As the participants noted, this study sheds light not only on the hardships they face, but also draws attention to ongoing strategies and new directions for African American farmers to maintain their farm land. One participant commented that through this study he had gained specific insights into the hardships of people he had known for years. Another participant reflected with others that his problems obtaining loans were not a reflection of his abilities as a farmer, but a systematic history of discriminatory practices. All participants agreed that sharing their stories is one way to address this history of discrimination and to curtail potential future practices. In addition, these farmers, with others across the state and nation, are working together on ventures that will ensure their economic viability for the long term. Innovations include ways to capitalize on the upsurge of interest in local, sustainable farming.

African American farming continues to be threatened by the lack of interested family members to whom the land can be passed. Participants have begun intentional outreach to recruit younger African Americans into farming. The experiences and perspectives of young, rural African Americans in regard to farming, however, are largely unknown. Participants and researchers alike recommend focusing future research in this area, and view engaging younger African Americans in farming as imperative in reducing further loss of farms or acreage.

The Photovoice methodology used for this study proved effective in eliciting rich experiences and perceptions of a group of African American farmers, as well as collectively developed action steps to maintain land ownership in their community. While the small sample size prohibits generalizability, the results can provide methodological and content direction for future studies on this topic. Along with the other action steps developed in this project and described above, this suggests future directions for community research, practice, and policy.

\section{Acknowledgments}

We would like to thank a number of people who helped in the community research and support of this manuscript, including Thomas Bullock, the late 
Jeff Hawkins, Dr. Eugenia Eng, and Gary Grant. We are also grateful for funding provided by the University of North Carolina Center for Poverty, Work, and Opportunity to the UNC Center for Health Promotion \& Disease Prevention to conduct this study.

\section{References}

Brondolo, E., Brady ver Halen, N., Pencille, M., Beatty, D. L., \& Contrada, R. J. (2009). Coping with racism: A selective review of the literature and a theoretical and methodological critique. Journal of Behavioral Medicine, 32 [Special Issue]: 64-88.

Brown, A., Christy, R. D., \& Gebremedhin, T. G. (1994, Spring). Structural changes in U.S. agriculture: Implications for African American farmers. The Review of Black Political Economy, 22(4): 51-71. doi:10.1007/BF02689979

Catalani, C. \& Minkler, M. (2009). Photovoice: A review of the literature in health and public health. Health Education \& Behavior, 37(3), 424-451. doi:10.1177/1090198109342084

Cowan, T. \& Feder, J. (2010). The Pigford cases: USDA settlement of discrimination suits by Black farmers. Congressional Research Service Report for Congress (RS20430). Retrieved from http://nationalaglawcenter.org/crs/

Escalante, C. L., Brooks, R. L., Epperson, J. E., \& Stegelin, F. E. (2006, April). Credit risk assessment and racial minority lending at the Farm Service Agency. Journal of Agricultural and Applied Economics, 38(1): 61-75.

Gilbert, J., Sharp, G., \& Felin, M. S. (2002). The Loss and persistence of Black-owned farms and farmland: A review of the research literature and its implications. Southern Rural Sociology, 18(2): 1-30

Grim, V. (1995). The Politics of inclusion: Black farmers and the quest for agribusiness participation, 19451990s. Agricultural History, 69(2): 257-271.

Harper, D. (2003). Framing photographic ethnography. Ethnography, 4(2): 241-246. doi:10.1177/14661381030042005

Havard, C. J. (2001). African-American farmers and fair lending: Racializing rural economic space. Stanford Law and Policy Review. Retrieved from http://www.nationalaglawcenter.org/assets/ bibarticles/havard african.pdf

Hinson, W., \& Robinson, E. (2008). 'We didn't get nothing": The plight of Black farmers. Journal of African-American Studies, 12: 283-302. doi:10.1007/s12111-008-9046-5
Hoffman, J. (2009). The last plantation. Colorlines. Retrieved from http://colorlines.com/archives/ 2009/01/the last plantation.html

Israel, B. A., Schulz, J., Parker, E., \& Becker, A. B. (1998). Review of community-based research: Assessing partnership approaches to improve public health. Annual Review of Public Health, 19: 173-202. doi:10.1146/annurev.publhealth.19.1.173

Jones, C. P. (2000). Levels of racism: A theoretic framework and a gardener's tale. American Journal of Public Health, 90: 1212-1215. doi:10.2105/AJPH.90.8.1212

Jones, J. M. (1997). Prejudice and racism (2nd ed.). New York: McGraw-Hill Companies.

Link, B., \& Phelan, J. (1995). Social conditions as fundamental causes of disease. Journal of Health and Social Behavior [Extra issue: Forty Years of Medical Sociology: The state of the art and directions for the future], 35, 80-94.

North Carolina Department of Agriculture \& Consumer Services [NCDA\&CS]. (2011). Small Farms Ag Policy-Services. Retrieved from http://www.ncagr. gov/SmallFarms/examples_of_services.htm

Paradies, Y. (2006). A systematic review of empirical research on self-reported racism and health. International Journal of Epidemiology, 35: 888-901. doi:10.1093/ije/dyl056

Prelow, H. M., Danoff-Burg, S., Swenson, R., \& Pulgiano, D. (2004). The impact of ecological risk and perceived discrimination on the psychological adjustment of African-American and European American youth. Journal of Community Psychology, 32(4): 375-389. doi:10.1002/jcop.20007

Ulin, P. R, Robinson, E. T., \& Tolley, E. E. (2005). Qualitative Methods in Public Health: A Field Guide for Applied Research. San Francisco: Jossey Bass.

U.S. Department of Agriculture [USDA]. (2003). USDA awards grants to assist socially disadvantaged farmers and ranchers. Retrieved from http://www.csrees.usda.gov/newsroom/news/ 2003news/assist ranchers.html

U.S. Department of Agriculture. (2009a). 2007 Census of Agriculture-Black Farmers. Retrieved from http://www.agcensus.usda.gov/Publications/2007 LOnline Highlights/Fact Sheets/black.pdf

U.S. Department of Agriculture. (2009b). 2007 Census of Agriculture-North Carolina State and County Data, Volume 1, Geographic Area Series, Part 33. Retrieved http://www.agcensus.usda.gov/ Publications/2007/Full_Report/Volume_1, Chapter 1 State Level/North Carolina/ncv1.pdf 
U.S. Department of Agriculture-Farm Service Agency [USDA-FSA]. (2007). USD A Minority Farm Register. Retrieved from http://www.apfo.usda.gov/ FSA/webapp?area=about\&subject=landing\& topic $=$ sao-oa-cr-ma

U.S. Department of Agriculture-National Agricultural Statistics Service [USDA-NASS]. (2011a). 2007 Census of Agriculture-Race, Ethnicity, and Gender Profile-North Carolina. Retrieved from http://www.agcensus.usda.gov/Publications/2007 OOnline Highlights/Race, Ethnicity and Gender Profiles/North Carolina/cpd99037.pdf

USDA-NASS. (2011b). Quick Stats 2.0 Website. Data retrieved from http://quickstats.nass.usda.gov/

Wallerstein, N. (1994). Empowerment education applied to youth. In Ana Consuelo Matiella (Ed.), Multicultural Challenges in Health Education. Santa Cruz, CA: ETR Associates.
Wang, C. C., \& Burris, M. (1997). Photovoice: Concept, methodology, and use for participatory needs assessment. Health Education \& Behavior, 24: 369387. doi:10.1177/109019819702400309

Wang, C., \& Redwood-Jones, Y. (2001, October). Photovoice Ethics: Perspectives from Flint Photovoice. Health Education and Behavior, 28: 547559. doi:10.1177/109019810102800504

Wood, S., \& Gilbert, J. (2000, Spring). Returning African-American farmers to the land: Recent trends and a policy rationale. The Review of Black Political Economy, 27: 43-64. doi:10.1007/BF02717262

World Health Organization. (2010). Social determinants of health. Retrieved from http://www.who.int/ social determinants/en/ 